\title{
Authority Management of Indonesian National Police Regarding Individual Criminal Responsibility Through Discretion
}

\author{
Viktor Theodorus Sihombing \\ \{viktortshb2501@gmail.com\} \\ Doctor of Law, Universitas Jayabaya, Jakarta, Indonesia
}

\begin{abstract}
There have been increases in the types of minor individual criminal cases during the Covid-19 Pandemic, requiring the police to develop law enforcement strategy that has legal certainty. Meanwhile, it is essential to apply adequate supervision and control over police actions to avoid misuse of discretion. Supervision and control are needed to prevent the occurrence of negative impacts in the forms of injustice in the implementation of discretion while police authority remains well-managed. This normative legal research was administered using empirical juridical approach, historical juridical, and comparative methods in analyzing and finding answers to research problems. In this research, descriptive analysis was performed to analyze primary and secondary data in the forms of primary, secondary, and tertiary legal materials. The data analysis was conducted using qualitative juridical analysis. The results showed that the Authority of Indonesian National Police regarding Individual Criminal Responsibility through Discretion could be regulated by determining the criteria and requirements for the implementation of discretion in the forms of regulations issued by the Chief of Indonesian National Police, including determination of authority, consideration, policy, decisions, actions, and preciseness. Whereas, legal certainty for the settlement of individual crime through discretion during the investigations by the Indonesian National Police relates to the elements of legal certainty, legal benefits and legal justice which can be regulated in Indonesian National Police Regulations on the Handling and Settlement of Crime Cases through Discretion. The law contains and describes other actions as referred to in article 16 paragraph (1) of Law Number 2 of 2002 concerning the Indonesian National Police.
\end{abstract}

Keywords: Authority; Criminal Responsibility; Discretion; Police.

\section{Introduction}

The latest data released by Indonesian COVID-19 Handling Task Force (2021) showed that by June 3rd, 2021, there were 1,837,126 confirmed positive cases, 1,691,593 recovered and 51,095 deaths. As explained by the National Institute of Allergy and Infectious Disease (Gillespie, 2020), the average annual death rate from flu is 0.1 percent, while Covid-19 is ten times more deadly. The data clearly indicate the impact of COVID-19 pandemic on Indonesia. The crime rate and its distribution including street crime and white-collar crime, individual crime and organized crime, both physical abuse and robbery kept increasing (Harkrisnowo, 2020).

Harkrisnowo (2020) believed that the most influential determinant on the crime rate and its distribution during this pandemic is the Large-Scale Social Restrictions (PSBB) policy. This policy demands compliance form the community to act on their own behalf in order to solve 
complicated problems that require quick handling. However, quick action from the community is lacking, and the legal basis for this policy has not yet been established by the legislature. In such condition, the state administrative law allows independent authority in the form of discretion (Ansori, 2015).

The government has taken different efforts to reduce the impact of the COVID-19 pandemic. However, these conditions will directly impact on higher crime rate among the community (Wardhana, 2020). The increasing crime rate requires the police to work harder (Wardhana, 2020). The Indonesian National Police needs to play its role in controlling the disease by educating the community and to handle crime cases that are closely related to the opportunity to conduct crime during the pandemic (Wardhana, 2020).

\section{Discretion}

In carrying out their duties, police officers sometimes have to take actions within their authority called discretion (Nugraha \& Ma'ruf, 2017). The definition of discretion according to the Legal Dictionary (2008) is the freedom to make decisions in every situation based on personal opinion. Discretion itself is defined as one of the means that allows officials or state administrative bodies to take actions without strong legal basis and to do actions that are goaloriented (doelmatigheid) rather the ones that conform with the law that apply (rechtmatigheid) (Ridwan, 2009).

As stated by Ansori (2015), the freedom of discretion is an administrative freedom which includes administrative freedom (interpretatieverijheid), freedom to make consideration (beoordelingsvrijheid), and freedom to make policies (beleidsvrijheid). Freedom of interpretation implies the freedom of government institutions to interpret a law (Ansori, 2015). Freedom of consideration arises when the law presents two choices (alternatives) of authority to certain requirements for government institutions (Ridwan, 2009). Meanwhile, the freedom to take policies is shown when legislators give authority to government institutions in carrying out their power to make an inventory and take into account different interests (Ridwan, 2009).

\section{Research Methods}

This research is a normative legal research that employed empirical juridical approach, historical juridical, and comparative methods to analyse and find answers to certain problems. Descriptive analysis was also performed to analyse primary and secondary data that consisted of primary legal materials, secondary legal material and tertiary legal materials. Primary data were also regarded as supporting legal materials for secondary data.

\section{Results and Discussion}

According to Article 1 point 1 of Law no. 2 of 2002 concerning the Police of the Republic of Indonesia, it is stated that "Police are all matters relating to the functions and institutions of the police in accordance with the laws and regulations." Meanwhile, Wardhana, (2020) mentioned three interpretations of the word police, namely: (1) Police as a function; (2) Police as a state organ; (3) Police as official/duty. In carrying out its function as law enforcement officers, the police must understand the legal principles in carrying out their duties as follows (Ilham, 2005): 
a. Legality; police officers as law enforcement officers have to comply with the law.

b. Obligation; refers to police's duties in handling discretion issues in the community which are not yet regulated by the law.

c. Participation: to enforce safety in the community, the police needs to conduct good coordination regarding neighbourhood safety watching to reinforce legal compliance.

d. Preventive; preventive actions should be prioritized before repressive ones.

e. Subsidiarity; carrying out the duties of other institutions to avoid bigger problems before being handled by the relevant institutions.

The complexity of police's tasks during the Covid-19 Pandemic is explained in Chapter III starting from Articles 13 to 14 of Law No. 2 of 2002. In this regard, during the Covid-19 pandemic, the main tasks of the National Police were reaffirmed by the issuance of several Telegrams from the National Police Chief as follows (Wardhana, 2020):

a. Telegram Letter Number ST/1098/IV/HUK.7.1/2020 onthe handling of potential crimes during large-scale social restrictions (PSBB) which contains the guidelines for police personnel in taking legal action.

b. Telegram Letter Number: ST/1099/IV/HUK.7.1/2020 which regulates the handling of crime in terms of foodstuffs provision and distribution.

c. Telegram Letter Number: ST/1100/IV/HUK.7.1/2020 which regulates the handling of crimes in cyberspace.

d. Telegram Letter Number ST/1101/IV/HUK.7.1/2020 which regulates the handling of potential crimes during the Large-Scale Social Restrictions.

e. Telegram Letter Number ST/1102/IV/HUK.7.1/2020 which regulates the handling of Indonesian workers (TKI) who have just arrived from countries affected by Covid-19.

Wardhana (2020) based on several telegrams issued by the National Police Chief pointed out at least two important roles of the National Police during the Covid-19 pandemic. First, in relation to the spread of disease, the National Police has a key role in implementing Health protocols. Second, in relation to law enforcement, the National Police plays a key in preventing and taking action against crime rate that increases during the pandemic.

In regards with Article 18 paragraph (1) of Law no. 2 of 2002, "for public interest, officers of the Indonesian National Police may act according to their own judgment." Hence, even when people violate certain order or do something based a pandemic, the police can still provide handling or law enforcement with their own assessment since it its under crucial circumstances. These duties should be performed by taking into account the laws and regulations, as well as the Professional Code of Ethics of the Indonesian National Police which gives limit to police's authority (Prasetyo, 2011):

1. The principle of necessity, that the action must be taken.

2. The actions taken are strictly within police's duties. The principle of purpose, that the most appropriate action to solve certain problems and to avoid greater consequence.

3. The principle of balance; the nature of the action or target used and the size of the problems should be balance regarding the impact of the object.

The Law no. 2 of 2002 anticipates excessive abuse of discretionary authority. Therefore, authorities that are regulated by the law are obtained through 3 (three) ways; attribution, delegation and mandate (Ridwan, 2009). Whilst, Stroink and Steenbeek (1985) only mentioned 2 (two) ways for government institutions to obtain authority; attribution and delegation. Attribution relates to the delegation of new authority, while delegation concerns the delegation of existing authority. Thus, delegation is logically always preceded by attribution.

Police's authority in implementing discretion needs to be ruled with clear criteria which are not yet explained in the Criminal Procedure Code (KUHAP). The Criminal Procedure Code 
only contains restrictions that function as a measure in using discretion. The Article 5 paragraph (1) letter a number 4 of the Criminal Procedure Code (KUHAP) and Article 16 paragraph 2 of the Law number 2 of 2002 concerning the National Police show that the term "other actions" refers to actions done by investigators to support the investigation.

\section{Conclusion}

Cases are within the preventive function of the police in terms of granting discretion are stronger than cases of law enforcement. Since the duties of the police are generally preventive tasks, these duties have broad scope and are not entirely ruled in a statutory regulation. In this case, police officers themselves have to make solutions which creates opportunity for discretion. In carrying out the special task of protecting the law against the application of discretion, police officers cannot be punished when they have to take the actions under the force of unavoidable power, under the context of self-defend, under statutory regulations, and under office order. The legal basis for Police Discretion includes the Law Number 2 Year 2002 Article 18 paragraph (1). Discretion can be carried out by police officers under necessary circumstances by taking into account the laws and regulations, as well as the Code of Professional Ethics of the Indonesian National Police.

\section{References}

[1] Ansori, L. (2015). "Diskresi Dan Pertanggungjawaban Pemerintah Dalam Penyelenggaraan Pemerintahan." Jurnal Yuridis, 2(1), 135-150.

[2] Gillespie, Claire. (September, 2020). "This Is How Many People Die from the Flu Each Year, according to the CDC." Meredith Health Group. Tersedia Pada: https://www.health.com/condition/infectious-diseases/coronavirus/cdc-mask-guidelines-when-towear

[3] Harkrisnowo, H. (2020). "Angka Kejahatan Dan Reaksi Sistem Peradilan Pidana Di Masa Pandemi Covid-19.” Jurnal Hukum Pidana dan Kriminologi, 1(1), 34-58.

[4] Nugraha, A. G., \& Ma'ruf, U. (2017). “Kewenangan Diskresi Dan Pertanggungjawaban Hukum Dalam Pelaksanaan Tugas Dan Fungsi Kepolisian.” Jurnal Hukum Khaira Ummah, 12(3), 507-516.

[5] Prasetyo, T. (2011). Hukum Pidana. Jakarta: PT. Raja Grafindo.

[6] Republik Indonesia. Undang-Undang No. 2 Tahun 2002 tentang Kepolisian Republik Indonesia. LN. 2002/No. 2, TLN No. 4168.

[7] Ridwan. (2009). Tiga Dimensi Hukum Administrasi dan Peradilan Administrasi. Yogyakarta: FH UII Press.

[8] Satuan Tugas Penanganan COVID-19. (Juni, 2021). "Data Sebaran Covid-19 di Indonesia.” Komite Penanganan Covid-19 dan Pemulihan Ekonomi Nasional. Tersedia Pada: https://covid19.go.id/

[9] Simorangkir, J. C. T., Erwin, R. T., \& Prasetyo, J. T. (2008). Kamus Hukum. Jakarta, sinar Grafika.

[10] Stroink, F. A. M. \& JG Steenbeek. (1985). Inleiding in het Staats-en Administratief Rech. Alphen aan den Rijn: Samson HD Tjeenk Willink.

[11] Wardhana, B. S. (2020). "Kompleksitas Tugas Kepolisian pada Masa Pandemi Covid-19.” Jurnal Ilmu Kepolisian, 14(2), 9. 